\title{
PELATIHAN PENGGUNAAN MEDIA SOSIAL UNTUK PEMASARAN DAN PENCATATAN KEUANGAN MENGGUNAKAN APLIKASI PADA UKM TENUN ENDEK DESA GETASAN
}

\author{
I Gede Suardika ${ }^{1 *}$, Ni Nyoman Harini Puspita ${ }^{1}$ \\ ${ }^{1}$ Sistem Informasi/Fakultas Informatika dan Komputer Institut Teknologi dan Bisnis STIKOM Bali \\ ${ }^{*}$ Coresponding-Author : suardika@stikom-bali.ac.id
}

\begin{abstract}
ABSTRAK. Perkembangan perekonomian saat ini mengarah ke wujud usaha masyarakat. Hal ini bertujuan untuk mewujudkan perekonomian masyarakat yang mandiri. Salah satu contohnya adalah kelompok usaha tenun kain endek di daerah Badung utara tepatnya di Desa Getasan, Kecamatan Petang, Provinsi Bali. Usaha ini bernama Fortuna Sari yang memiliki lima belas pengerajin. Usaha kelompok Tenun ini berdiri semenjak Mei 2014. Pangsa pasar yang saat ini dimiliki berjualan di sekitar lokasi usaha dan dari luar desa yang merupakan relasi dari pengurus, seperti Dinas, Desa, organisasi dan perorangan. Media pemasaran saat ini belum memanfaatkan media pemasaran online seperti media sosial dan website yang dimiliki memiliki domain yang tidak mencerminkan produk. Selain itu proses pencatatan pendapatan dan pengeluaran dari usaha ini menggunakan masih buku tulis. Berdasarkan hal tersebut maka, pengabdian ini akan dilaksanakan dalam dua aspek, yaitu mengajarkan penggunaan media online secara maksimal dan mengajarkan untuk menggunakan aplikasi Excel untuk pencatatan pengeluaran dan pendapatan. Dalam pelatihan ini juga dibantu membuatkan video yang menjelaskan kualitas tenun yang diproduksi. Situasi yang mendukung pengabdian ini akan terlaksana adalah pengurus memiliki kemampuan menggunakan komputer dan media sosial. Hasil dari kegiatan ini adalah, mitra telah memiliki media sosial untuk memasarkan produk, memiliki media seperti video yang menjelaskan kualitas kain tenun yang diproduksi. serta telah bisa menggunakan aplikasi Google Form dan Excel di Googel Drive untuk mengelola keuangan.
\end{abstract}

Kata Kunci: Tenun Bali, pemasaran, pencatatan keuangan

\begin{abstract}
The current economic development leads to a form of community business. This aims to create an independent community economy. One example is the endek cloth weaving business group in the North Badung area, precisely in Getasan Village, Petang District, Bali Province. This business is called Fortuna Sari which has fifteen craftsmen. The weaving group business was founded in May 2014. The market share currently owned is selling around the business location and from outside the village which is the relationship of the board, such as the Dinas, Villages, organizations and individuals. Currently, marketing media have not utilized online marketing media such as social media and their websites have domains that do not reflect the product. In addition, the process of recording income and expenses from this business is still a notebook. Based on this, this service will be carried out in two aspects, namely teaching the use of online media to the fullest and teaching to use the Excel application to record expenses and income. In this training, we will also be assisted in producing a video explaining the quality of the weaving produced. The situation that supports this service will happen is that the board has the ability to use computers and social media. The result of this service is that the weaving business group can use online media to the fullest, have a video explaining the quality of fabrics that are characteristic and product advantages, can use the Excel application to record income and expenses.
\end{abstract}

Keyword: Balinese weaving, marketing, financial records 


\section{PENDAHULUAN}

Indonesia adalah ekonomi terbesar di Asia Tenggara (Rezki, 2011). Indonesia memiliki potensi ekonomi yang tinggi, potensi yang mulai diperhatikan dunia internasional dan memiliki sejumlah karakteristik yang menempatkan negara ini dalam posisi yang bagus untuk mengalami perkembangan ekonomi yang pesat (Belinan Lamanuk \& Erna, 2020). Salah satu contohnya adalah usaha produksi kain endek yang merupakan kain khas daerah Bali yang diproduksi dengan proses tenun tradisional.

Fortuna Sari Bali ini adalah nama kelompok usaha endek tenun ikat yang berlokasi di Badung utara tepatnya di Desa Getasan Kecamatan Petang, Kabupaten Badung, Provinsi Bali. Tenun ikat atau kain ikat adalah karya tenun Indonesia berupa kain yang ditenun dari helaian benang pakan atau benang lungsin yang sebelumnya diikat dan dicelupkan ke dalam zat pewarna alami (Aditia Wiguna \& Putera Permana, 2019). Alat tenun yang dipakai adalah alat tenun tradisional, bukan mesin. Kain ikat dapat dijahit untuk dijadikan pakaian dan perlengkapan busana, kain pelapis mebel atau penghias interior rumah. Sebelum ditenun, helaian benang dibungkus (diikat) dengan tali plastik sesuai dengan corak atau pola hias yang diinginkan. Ketika dicelup, bagian benang yang diikat dengan tali plastik tidak akan terwarnai. Tenun ikat ganda dibuat dari menenun benang pakan dan benang lungsin yang keduanya sudah diberi motif melalui teknik pengikatan sebelum dicelup ke dalam warna. Kelompok tenun ikat Fortuna Sari Desa Getasan berupaya mengangkat motif selaras dengan alam, adat dan budaya sekitar desanya dengan mendesain motif-motif yang kekinian namun tidak meninggalkan budaya daerah. Usaha kelompok tersebut berusaha maksimal untuk bisa menghasilkan kain tenun ikat berkualitas dengan harga bersaing, sehingga dengan hal ini diharapkan dapat menarik minat masyarakat khususnya anak muda untuk mengenal dan menggunakan kain tenun ikat endek Bali sebagai busana sehari-hari atau busana resmi ke kantor atau acara-acara tertentu lainnya (Ari Dharmayoga, Wirabuana Putra, \& Endra Priantono, 2013). Kelompok usaha ini memiliki web profile dengan alamat https://fortunasaribali.com.

Setelah dianalisis dari nama web profile tidak ditemukan saat pencarian dengan kata kunci "endek tenun" di web, hal ini berarti nama website kurang mendukung branding di dunia maya. Isi dari website juga kurang diperbaharui dan tampilan produk masih foto standar, dimana jika mau melihat detail kain belum bisa. Tentunya hal ini menjadi kurang menarik untuk penjelajah dunia maya yang terbiasa berbelanja secara online. Saat ini peminat pembelian barang secara online sangat dipengaruhi oleh cara penyajian dan penayangan secara audio dan visual.
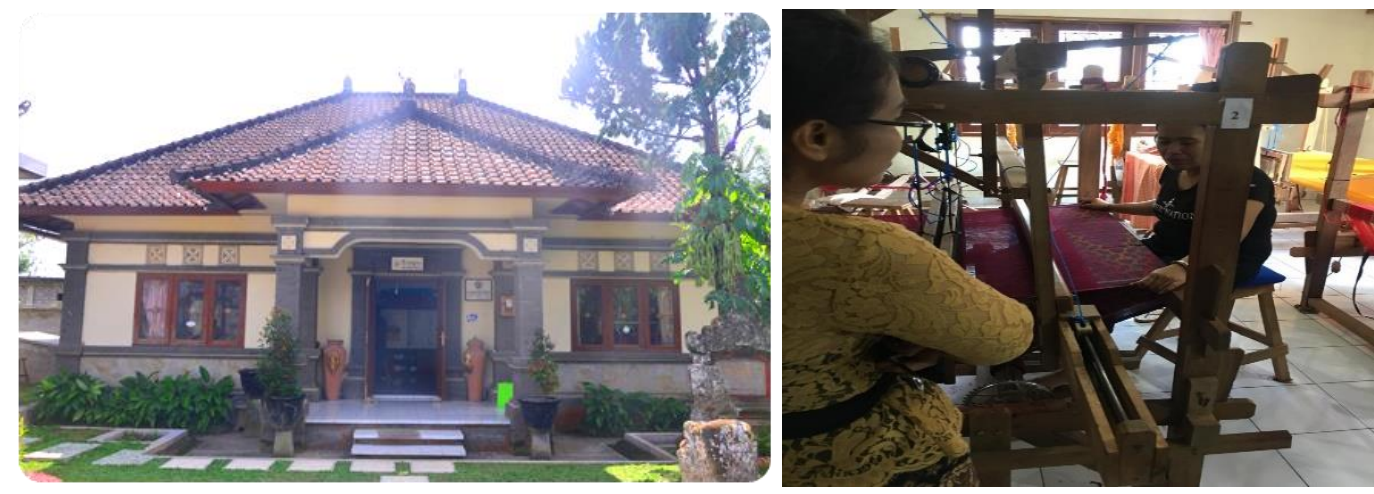

Gambar 1. Tempat usaha endek tenun ikat Desa Getasan

Pemilik dan pegawai merupakan pengelola yang terbiasa menggunakan smartphone, dan untuk administrasi yang didukung oleh desa ada sebuah perangkat laptop, dimana hal ini dapat mendukung proses pengabdian yang akan dilaksanakan. Jumlah pegawai sebagai pengerajin tenun pada usaha ini sebanyak 15 orang dengan manajer 1 orang. Pengerajin bekerja 8 jam per hari, 
dengan rata-rata menghasilkan hasil tenun endek 1,5meter hari per orang. Adapun uraian pendapatan dari proses produksi yang diperoleh oleh kelompok usaha dapat dilihat pada Tabel 1.

Tabel 1. analisis situasi mitra pengabdian

\begin{tabular}{|c|c|c|c|}
\hline Kegiatan & Keadaan saat ini & Keterangan & Permasalahan \\
\hline Mesin & 30 alat tenun & Kondisi baik & $\begin{array}{l}\text { Jumlah pengerajin hanya } 15 \\
\text { jadi yang digunakan } \\
\text { sebanak } 15 \text { alat tenun }\end{array}$ \\
\hline $\begin{array}{l}\text { Bahan baku } 1 \text { set alat } \\
\text { tenun }\end{array}$ & 4.000 .000 & 15 alat tenun & $\begin{array}{l}\text { SDM yang aktif rata-rata } 10 \\
\text { orang }\end{array}$ \\
\hline Hasil poduksi 1 mesin & 72 meter & 3 bulan & $\begin{array}{l}\text { Harusnya ini target selesai } \\
1 \text { bulan }\end{array}$ \\
\hline Hasil 1 hari / orang & 1,5 meter & 15 meter & $\begin{array}{l}\text { Seharusnya per hari taget } \\
\text { hasil adalah } 22,5\end{array}$ \\
\hline Penjualan / bulan & $25 \%$ dari hasil produksi & 13.500 .000 & $\begin{array}{l}\text { Penjualan per bulan target } \\
54.000 .000\end{array}$ \\
\hline $\begin{array}{l}\text { Order dalam partai } \\
\text { besar (> 500meter } \\
\text { untuk waktu singkat) }\end{array}$ & & & $\begin{array}{l}\text { Tidak bisa diambil karena } \\
\text { kekurangan SDM }\end{array}$ \\
\hline $\begin{array}{l}\text { Pencatatan penjualan } \\
\text { dan pembelian } \\
\text { bahanbaku }\end{array}$ & Menggunakan buku & & $\begin{array}{l}\text { Jika ada lupa mencatat } \\
\text { maka akan sulit menelusuri } \\
\text { ketidakseimbangan catatan } \\
\text { hasil produksi dan } \\
\text { penjualan. }\end{array}$ \\
\hline SDM yang ada & $\begin{array}{l}\text { Menggunakan } \\
\text { smartphone dan } \\
\text { memiliki media sosial }\end{array}$ & & $\begin{array}{l}\text { Belum dimanfaatkan untuk } \\
\text { penjualan }\end{array}$ \\
\hline
\end{tabular}

\section{ANALISIS PERMASALAHAN}

Permasalahan kelompok usaha endek tenun ikat Getasan ini mencakup hal-hal berikut. Mitra belum menggunakan media sosial ataupun memanfaatkan web yang dimiliki untuk pemasaran. Hal ini berdampak produk endek tenun daerah Getasan tidak dikenal banyak orang. Pemasaran hanya dilakukan dari mulut ke mulut, daerah cakupan yang terbatas di sekitar lokasi mitra dan relasi. Mitra tidak memiliki media seperti video yang menjelaskan kualitas kain tenun yang diproduksi. Mitra melakukan pencatan pendapatan dan pengeluaran masih dilakukan secara manual menggunakan buku sehingga mitra merasa kesulitan untuk melihat laporan pada saat diperlukan dan ketika terjadi kesalahan dalam pencatatan, mitra juga mengalami kesulitan untuk menelusuri kesalahan dan memperbaikinya.

\section{SOLUSI YANG DITAWARKAN}

Solusi dari permasalahan mitra diuraikan sebagai berikut:

1. Memberikan pengetahuan tentang manfaat berjualan online melalui media sosial dan market place yang ada.

2. Memberikan bantuan membuat video untuk menjelaskan keunggulan produk tenun ikat yang diproduksi.

3. Mengajarkan mitra menggunakan aplikasi Excel untuk mengelola keuangan UKM.

Pelaksanaan untuk mengatasi permasalahan disesuaikan dengan bidang permasalahan yaitu:

1. Sosialisasi tentang kegiatan yang berupa pengambilan video dan pelatihan yang akan diadakan dan menentukan kesepakatan jadwal pelaksanaan. 
2. Mempersiapkan skenario pengambilan video dan modul pelatihan.

3. Menjelaskan fasilitas pendukung seperti internet yang harus disediakan oleh peserta.

4. Pelaksanaan pelatihan menggunakan aplikasi untuk pencatatan proses keuangan.

5. Pembuatan laporan hasil pengabdian.

Partisipasi masyarakat umum dalam kegiatan ini adalah disediakannya tim teknis sesuai dengan bidang ilmu dan kompetensi, yaitu di bidang Komputer. Peserta juga berpartisipasi aktif dalam kegiatan pengabdian ini, yaitu menyediakan tempat, fasilitas dan waktu untuk mendukung kelancaran kegiatan ini.

Evaluasi kegiatan dilakukan setiap 3 bulan untuk melihat apakah hasil pelatihan tetap dijalankan secara konsisten. Evaluasi juga dilakukan dengan menyebarkan kuesioner. Keberlanjutan dari kegiatan pengabdian ini akan terus dijalankan dalam proses pemasaran.

Dalam pelaksanaan pengabdian ini terdiri dari satu orang Ketua yang memiliki kompetensi dalam bidang ilmu Komputer yang dapat memberikan materi dalam teknis pemanfaatan media online pemasaran. Dua orang anggota yang salah satunya adalah Dosen yang juga memiliki kompetensi dalam Komputer yang dapat memberikan pelatihan penggunaan aplikasi Excel dalam pengelolaan keuangan. Satu orang mahasiswa yang membantu dalam membuat video yang menjelaskan ciri khas dari endek yang diproduksi.

\section{HASIL DAN PEMBAHASAN}

Adapun susunan kegiatan dalam kegiatan pengabdian masyarakat ini dapat digambarkan dalam Tabel 2.

Tabel 2. Susunan kegiatan pengabdian

\begin{tabular}{lll}
\hline No & Kegiatan & Keterangan \\
\hline 1 & Kunjungan sosialisasi rencana kegiatan & 1 hari \\
2 & Kunjungan untuk melakukan shooting untuk video & 1 hari \\
3 & Memberikan Pelatihan penggunaan media social untuk pemasaran & 1 hari \\
4 & Memberikan pelatihan pencatatan keuangan dengan apliaksi Excel & 1 hari \\
\hline
\end{tabular}

Kegiatan pelatihan dilakukan pada hari Selasa, 14 Januari 2020 bertempat di Ruang Administrasi UKM Tenun Endek Fortunasari di Desa Getasan. Pelatihan dilaksanakan selama 3 jam mulai dari pukul 13.00 s.d 16.00 . Kegiatan yang dilakukan memberikan pelatihan tentang manfaat promosi melalui media social agar lebih banyak masyarakat yang mengetahui produk yang dijual. Selain memberikan pelatihan secara teknis, juga diberikan tips untuk selalu memberikan deskripsi singkat dan jelas beserta kelebihan dari produk yang dimiliki. Pelatihan kedua dilakukan pada hari Rabu 20 Mei 2020 dari pukul 10.00 s.d pukul 13.00.

Kegiatan pembuatan video dilakukan terpisah dari kegiatan pelatihan, sehingga dihasilkan sebuah video singkat dalam durasi 2 menit yang menggambarkan secara umum Kualitas dari Endek Tenun Desa Getasan. Video ini berisi tentang penjelasan ciri khas dari endek tenun yang diproduksi. Yang menceritakan bahwa endek yang dihasilkan memiliki kualitas kain yang lebih rapat dan tebal.

Pelatihan pemasaran online dimulai dengan mengganti domain web http://fortunasaribali.com dengan nama endektenunbali.com. tujuannya adalah pada saat pencarian di internet dengan kata kunci endek, alamat web bisa ditemukan. Kemudian diikuti dengan pelatihan pemanfaatan media social dalam berjualan. Pelatihan juga diikuti dengan bagaimana cara menggunakan Facebook Ads. 
Fortunasardbalicom

Sudut Informasi Produk

-

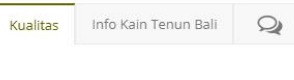

Bahan Berkualitas \& Desain Terkini

Produk kain yang kami tawarkan adalah kain dengan kualitas sangat memuaskan. Bahan dengan mengenakan balutan kain tradisional khas Bali.

- Download Katalog Produk

- Gallery Produk

- Kirim Pesan ke Email Kami
Postingan Terbaru

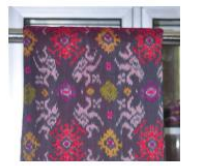

Sejarah Kain Tenun Khas Bali

Hal unik dari kain endek ini terletak pada motif yang beragam. Beberapa motif kain endek dianggap sakral. Hanya boleh digunakan untuk kegiatan-kegiatan di pura

Gambar 2. Halaman web endek tenun

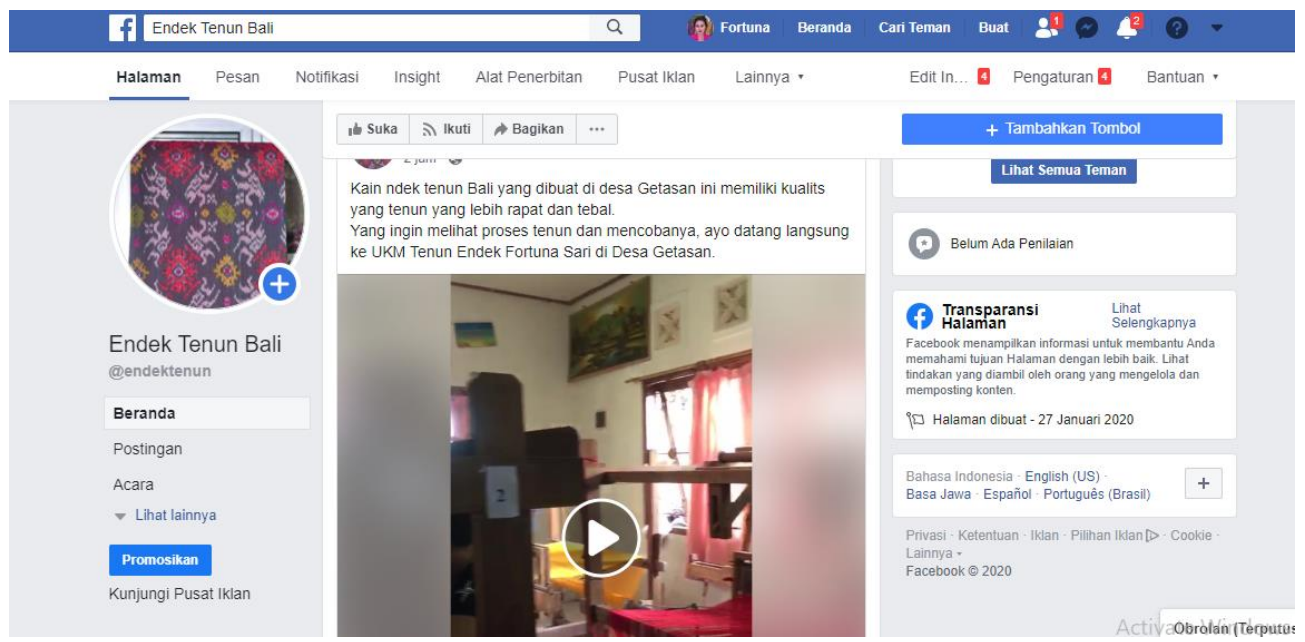

Gambar 3. Tampilan pemasaran melalui media sosial

Pelatihan mengelola keuangan diberikan dengan memanfaatkan aplikasi Google Form dan Excel di Google Drive. Pada awalnya pengelolaan keuangan direncanakan menggunakan aplikasi online yang tersedia, namun karena mempertimbangkan data keuangan bersifat rahasia maka digunakan Excel di Google Drive dan pelaporan hasil kerja harian melalui Google Form sehingga para pegawai tetap bisa melaporkan hasil pekerjaan per hari, dan manager juga bisa memantau setiap hari. Dalam pelatihan ini kami menyiapkan template pencatatan keuangan di Spreadsheet Google Drive berupa: hasil harian pegawai (ditunjukkan oleh gambar 4) dan bentuk buku kas (ditunjukkan oleh gambar 5).

\section{Endek Tenun Getasan}

Catatan harian hasil tenun endek

Nama Pegawai

Choose $\quad-$

Gambar 1. Google Form Hasil Harian Pegawai 


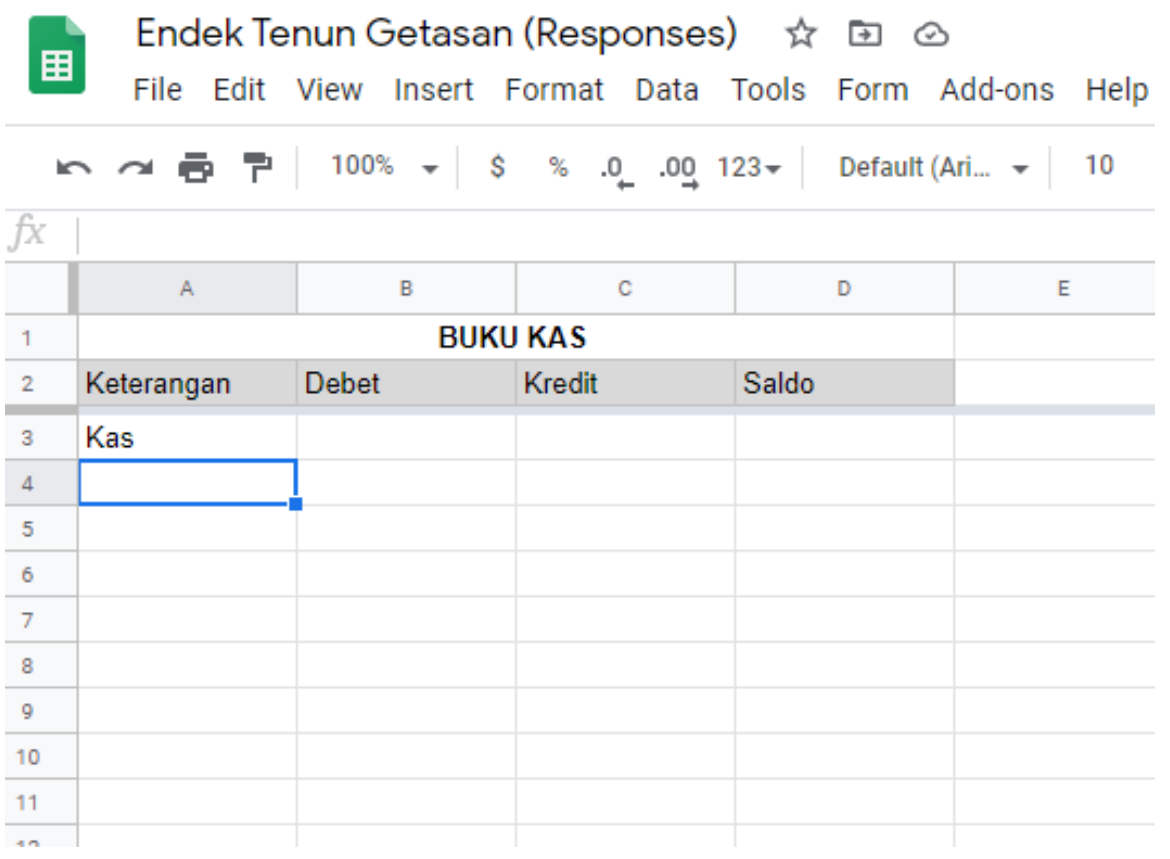

Gambar 2. Buku Kas

Evaluasi kegiatan dilakukan dengan menyebarkan kuesioner kepada peserta dengan hasil yang terlihat pada Tabel 3. Terlihat bahwa beberapa kriteria penilaian seperti tema kegiatan, ketepatan waktu, sikap pelaksanaan tim, kepuasan pelaksanaan, dan tentang infrastruktur mendapatkan nilai memuaskan minimal sebanyak $80 \%$ dari jumlah peserta. Hal yang paling menarik bagi peserta adalah tentang materi, sebanyak $67 \%$ peserta menyatakan hal tersebut.

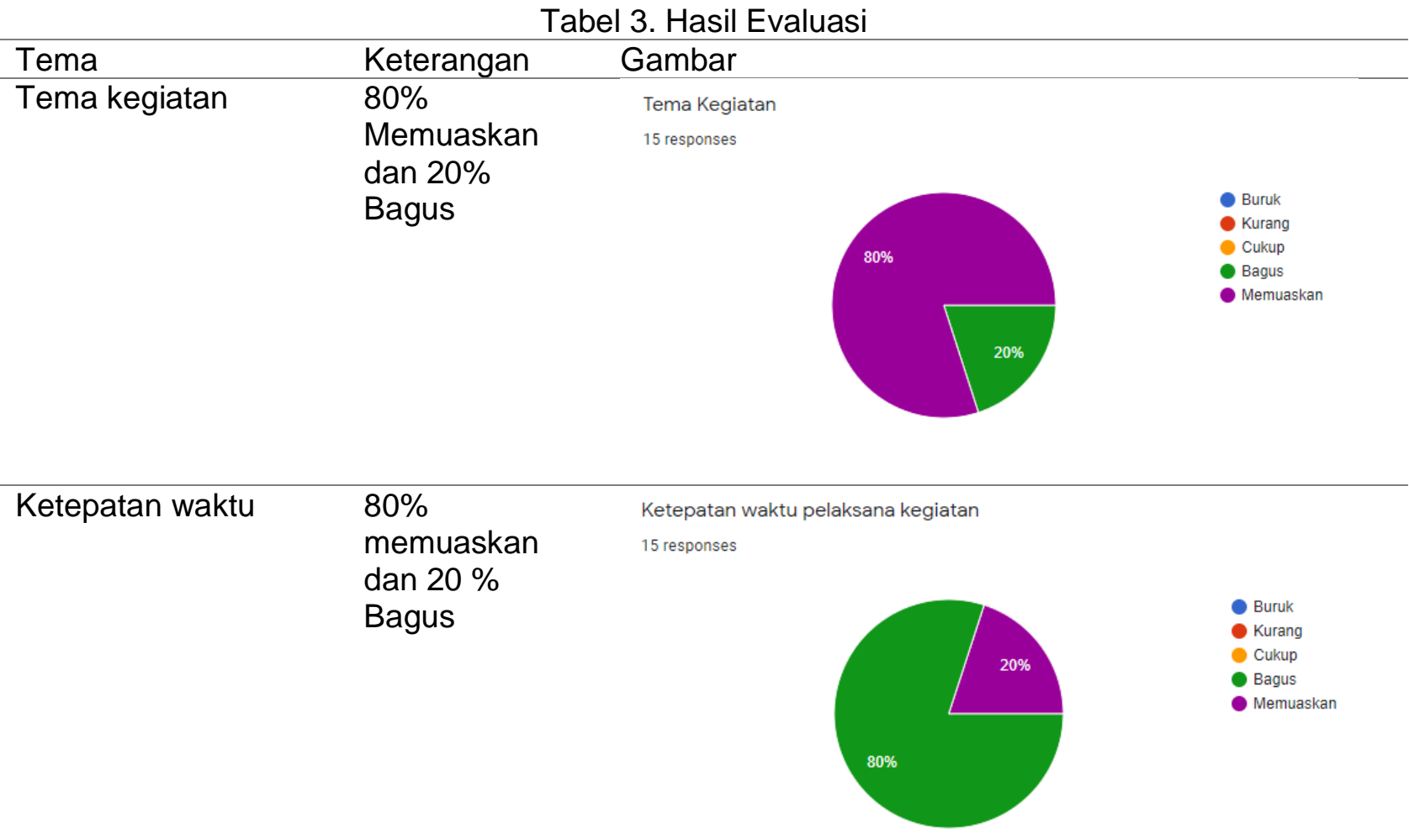




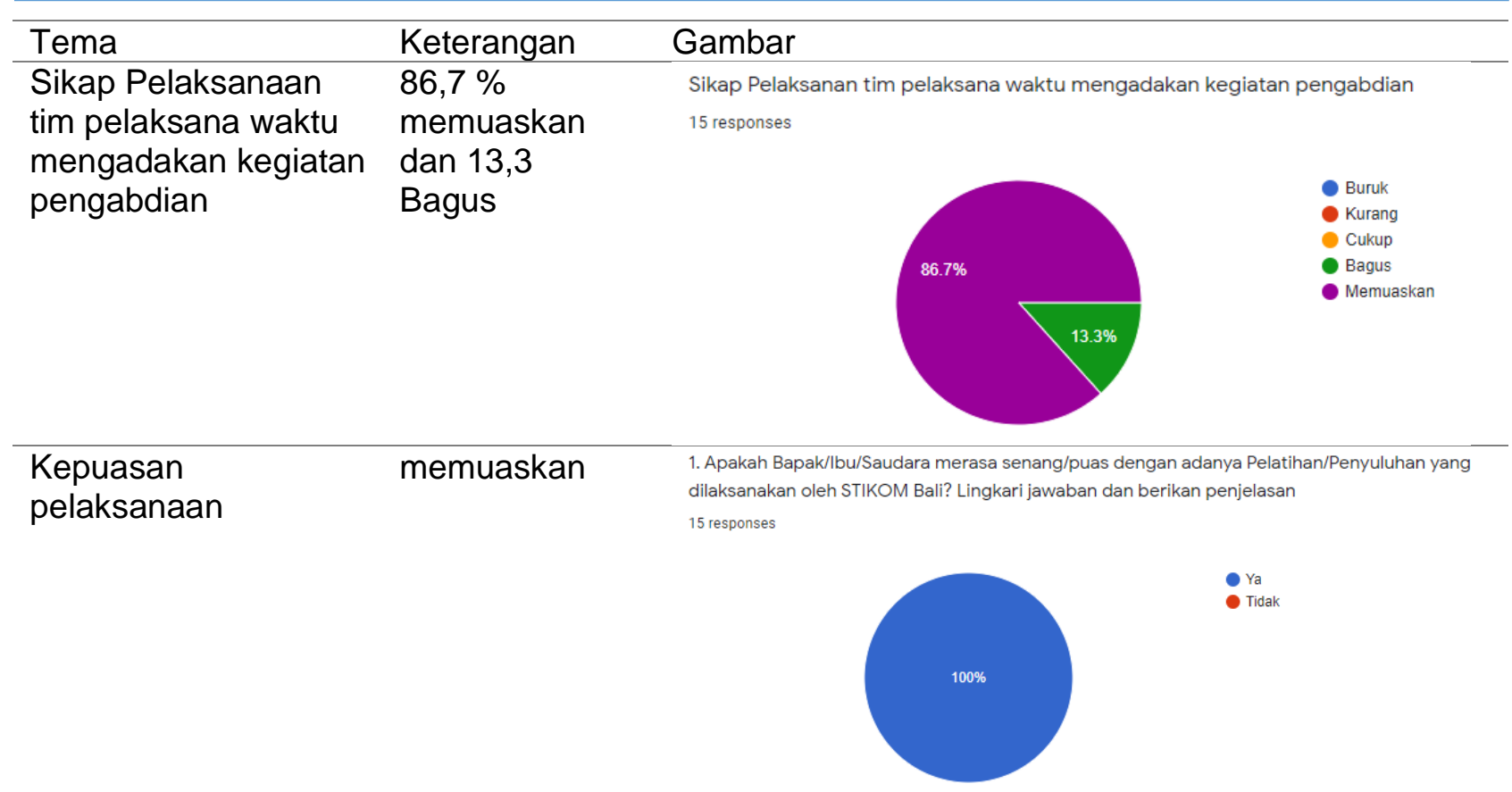

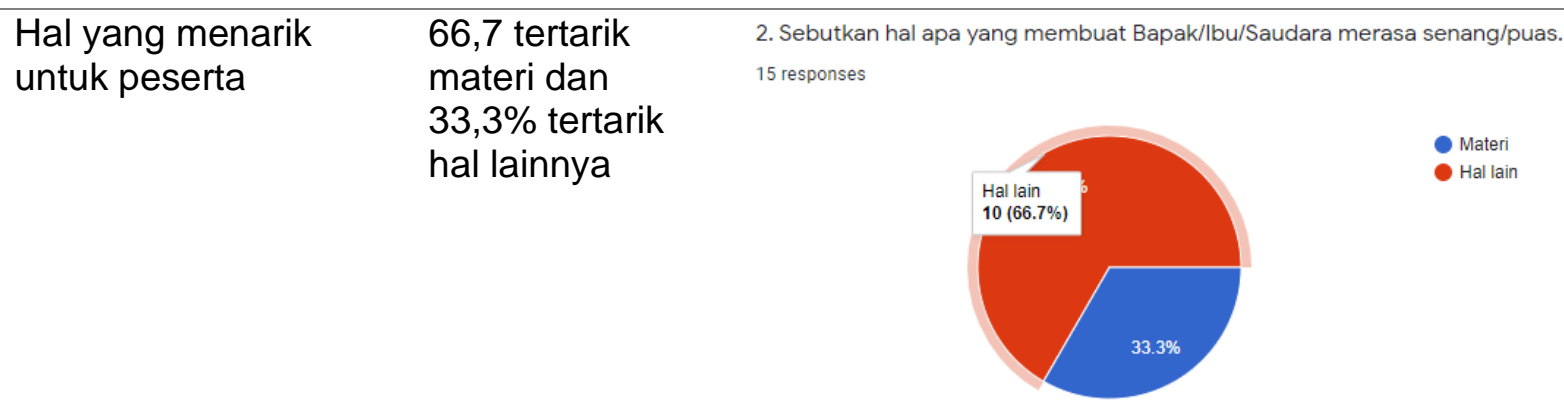

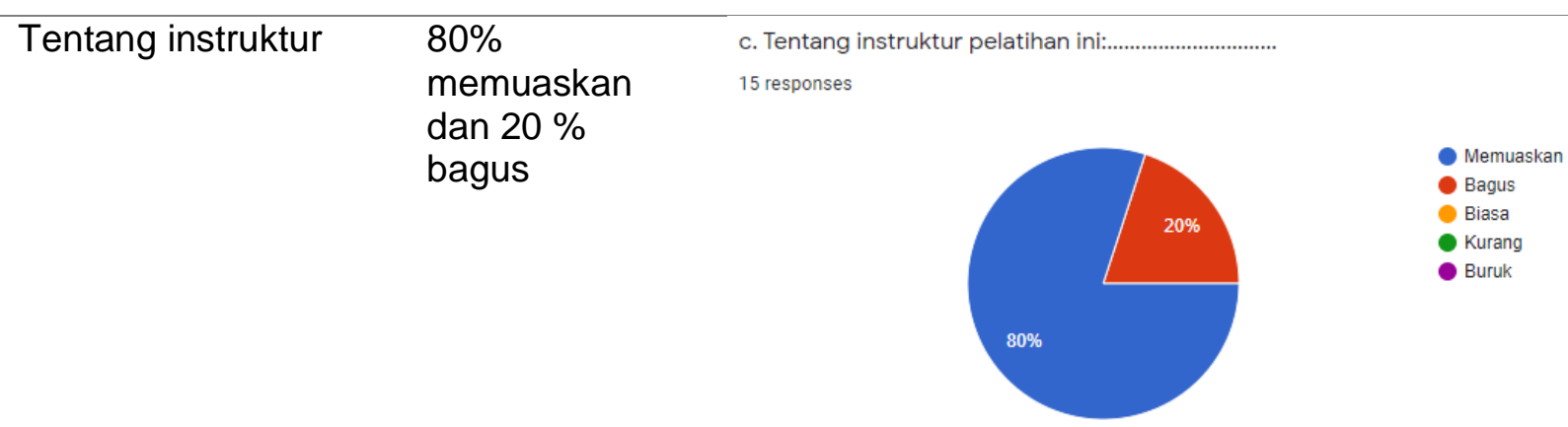

\section{KESIMPULAN}

Berdasarkan uraian di atas dan evaluasi pelatihan yang diberikan, maka dapat disimpulkan beberap hal sebagai berikut.

1. Hasil dari kegiatan ini adalah, mitra telah memiliki media social untuk memasarkan produk, mitra memiliki media seperti video yang menjelaskan kualitas kain tenun yang diproduksi. mitra telah bisa menggunakan aplikasi Google Form dan Excel di Googel Drive untuk mengelola keuangan.

2. Peserta berpartisipasi aktif dalam kegiatan pengabdian ini, yaitu menyediakan tempat, fasilitas dan waktu untuk mendukung kelancaran kegiatan ini 
3. Sebanyak minimal $80 \%$ peserta menyatakan puas terhadap beberapa kriteria penilaian seperti tema kegiatan, ketepatan waktu, sikap pelaksanaan tim, kepuasan pelaksanaan, dan tentang infrastruktur.

4. Sebanyak $66.7 \%$ dari jumlah peserta menyatakan bahwa hal yang paling menarik adalah tentang materi pelatihan.

\section{REFERENSI}

Aditia Wiguna, F., \& Putera Permana, E. (2019). DinamikalndustriTenun Ikat ATBM Bandar Kidul Kediri Jawa Timur. Efektor, 6(2), 120-126.

Ari Dharmayoga, I., Wirabuana Putra, G., \& Endra Priantono, I. (2013). Pemanfaatan Endek Sebagai Sepatu Guna Menarik Minat Generasi Muda Melestarikan Budaya Bali. Pekan IImiah Mahasiswa Nasional Program Kreativitas Mahasiswa - Kewirausahaan 2013. Jakarta: Ristekdikti.

Belinan Lamanuk, N., \& Erna, F. (2020). Pengaruh Bauran Pemasaran Terhadap Keputusan Pembelian Serta Dampaknya Terhadap Kepuasankonsumen Kampoeng Roti Disurabaya. Seminar Nasional IImu Terapan IV (hal. B-18-1 - B-18-9). Universitas Widya Kartika.

Rezki, J. F. (2011). Konsumsi Energi dan Pembangunan Ekonomi di Asia TenggaraEnergy Consumption and Economic Development in South East Asia. Jurnal Ekonomi dan Pembangunan Indonesia, 12(1), 31-38. 